\title{
Creating an Intercultural Space. The Roles of 'African' and 'Western' in the Discourses About Science and Faith in Yaoundé, Abidjan, and Kinshasa
}

The start of the field research felt like an adventure. Field research in the area of science and faith is scarce, and we don't know of any examples from Africa. When we started the field research in 2015, we had no knowledge of the use of Group Model Building (GMB) in theological research, nor of its application to people groups on the African continent. ${ }^{1}$ It goes without saying that we were even more excited about what the participants would communicate to us. As explained in Chapter 3, in Abidjan and Yaoundé, the national education programs are dominated by the typical French idea of laïcité. It seemed realistic to expect that this principle that creates a sharp distinction between science and faith might have shaped the participants' understandings. With these and many other thoughts in mind we arrived in Yaoundé at the end of May 2015 and started the first round of research. During two long GMB-sessions we recorded the deliberations of two groups: one composed of students and the other of academics. These sessions were held at the siL centre on the green hills of the Mvan neighbourhood in the South-East of the city. ${ }^{2}$ Heaven's rains were abundant, and a power cut briefly interrupted our sessions. The rain, however, did not stop the participants from coming to the research meetings. In the case of the students we sat together for three and a half hours in order to build a model. With the academics we had a smaller group and the session was somewhat shorter. After the sessions we were all exhausted and enjoyed a nice local meal together. Despite our exhaustion the debates even continued during the meal, and we were struck by the engagement and interest that the participants demonstrated.

1 Initially, we relied on Arensbergen e.a. 2016 which does not mention this use of GMB in Africa. However, thanks to our colleague Thandi Soko - de Jong, we recently discovered that GM B was applied to analyse Health Systems Resilience in Ivory Coast, Nigeria and South Africa. See https://rebuildconsortium.com/media/1226/hsr_scripts-for-group-model-building _october-2015.pdf (accessed 22 October 2018).

2 SIL is an institute for language development and translation. See https://www.sil.org/ program/idelta-fr accessed on 22 October 2018. 
In this and the next chapter we will tell the story of the research sessions in Yaoundé, Abidjan, and Kinshasa, and will present and analyse the participants' discourses about science and faith. GM B helped us to reconstruct and analyse the discourses with the help of the participants. The text of these chapters is based on the building and analysis of the models construed and developed by the participants. These models can be found in the annexes. We pay special attention to the way science and faith are approached in the discourses. In the debate held by the student group from Yaoundé, the cultural difference between Africa and Europe (or the West) appeared to play a prominent role, and we also recognized this feature in the discourses of the other groups. In comparison to Western literature on science and faith, this intercultural approach is a remarkable characteristic of the African perspective (see Chapter 7). The specific way in which the Yaoundé student group dealt with this cultural difference helped us to formulate a hypothesis that focused the analysis of all the group discourses presented in this chapter. As we argue below, the two main tendencies related to the use of 'African' and 'Western' among the students from Yaoundé produced a dynamic that functions as a tool for discussing the questions concerning science and religion. Due to the intentional use of this dynamic, we label this way of handling the discussion 'intercultural framing'; a term we explain below.

When we touch on the importance of the dynamics within-group, we are aware that we are including elements that are not always tangible. For example, the varying ambience in which the debates took place are not easy to describe; sometimes very lively, but in some groups also very cautious and hesitant; at times dynamic and other times dull and repetitive; and occasionally sharp, but now and then confused. We hope we can share something of these dynamics in these chapters.

In the first part of the chapter we present an analysis of the use of 'African' and 'Western' in the different groups. We begin with the discourse of the student group from Yaoundé and analyse the procedure we just labelled 'intercultural framing'. Afterwards, we analyse the ways in which 'African' and 'Western' are used in the other groups to determine whether a similar dynamic can also be identified in these discussions. This does not appear to be the case in all groups, although cultural difference is a major theme in every group. Since our analysis of the discourses in the first part of this chapter is much longer than in the other parts, it is divided into subsections. In the second part of this chapter we look more specifically at the relationship between the conceptions of culture used in the different groups and the contexts in which they are used. In the final part we offer a comparison of the groups to identify the unique and shared aspects of the (inter)cultural framing of science and faith among the 
groups. At the end of this chapter there is a table of comparison, which provides an overview of the six groups. In the next chapter we will investigate how the cultural understandings affects the way science and faith are understood.

\section{Part 1: The Use of 'African' and 'Western' in the Different Groups}

We start with the discourses from Yaoundé, which are described more extensively than those from the other cities. There are two main reasons for taking the Yaoundé case as the point of departure and primary reference. In the first place, the participation of the student group from this city was the most stable of all the groups. During the three research sessions the group of participants remained constant, which was not the case anywhere else (see Chapter 2). A second reason for focusing on the Yaoundé discourses is that although cultural difference (especially between 'African' and 'Western') was an important theme in all the groups, it nowhere led to such controversies as was the case in both Yaoundé groups.

Subsequently, we turn to the discourses from Abidjan, where the use of 'African' and 'Western' played a different role, mainly due to the specific political context of Ivory Coast. Finally, we present the critical case of the discourses from Kinshasa, which does not share the colonial heritage of laïcité as the other contexts do. ${ }^{3}$

\subsection{Yaoundé}

Before focusing on the discourses of the groups in Yaoundé, we remind you that Cameroon is highly diverse culturally (see Chapter 3 ), and this is reflected in the research population. For example, students Brice and Junior are from different people groups in the so called 'Far North' of the country, near lake Chad. Others, such as Enow and Ayuk, are from the coastal area, while Esek and Patrick are from the central region. Among the participants there is also a sizeable group from West Cameroon who have a Bamileke background including Janvier, Joaddan, and Loïc from the student group and Martha from the academic group. We will return to the topic of cultural diversity in the next paragraph.

3 For more on the role of the discourse from Kinshasa as a critical case, see Chapters 2 and 3. 
From the very start of the discussion among the Yaoundé students, the variable termed 'African culture' played an important role. ${ }^{4}$ The discussion of themes related to the key concepts 'Bible' and 'African culture' took up most of the GMB session, and was also a leading topic in the two focus group sessions. The continuing debate about this point indicated that it was not completely resolved. In the group, we distinguish two distinct subgroups and what could be called 'the rest' - a far less outspoken group that nevertheless engages when a decision is required. The first subgroup defends a mainly harmonious and constructive relationship between the Bible and African culture. Brice, one of the most prominent defenders of this view, is a remarkably tall and elegantly dressed student of education from a Protestant-evangelical background. When the group underlines a positive contribution from the Bible towards African culture, he argues that the contribution is primarily in the opposite sense: "My African culture, my African identity improves my understanding and contextualization of the Bible. When I am more anchored in my culture [...] I have a comprehensive, profound reading of the Bible." The use of 'African' in relation to culture and even identity is remarkable because Brice clearly refers to a particular culture in the Far North of Cameroon.

Patrick, an eloquent linguist from a Protestant-evangelical background, supports Brice's perspective to a certain extent. He claims that Bible reading always happens from a particular cultural context and argues that early African church fathers like Origen and Saint Augustine were "anchored in their culture" as well. ${ }^{6}$ Patrick is the only one in the student group from Yaoundé that makes explicit references to the Pan-Africanist stance. ${ }^{7}$ Among the academics

4 See figure YS2 in the Annexes to see the model built by the students from Yaoundé. On the right-hand side of the model 'African culture' received a prominent place. Most of the discussions concentrated on the relationship between 'African culture' and 'Bible' and are represented by the arrows between these two concepts. Initially, there was a group among the students (especially Enow) that defended a negative arrow between 'African culture' and 'Bible', but eventually they dropped this point.

5 For the references to the quotes, we use the Atlas-ti indications: $P$ followed by a number between 1 and 19 refers to the transcription of a specific session, the next number refers to a specific quote; $x x x$ refers to a inaudible word. $P_{5}, 175$ : “[...] Ça veut dire que ma culture africaine, mon identité d'africain me permet mieux d'appréhender et de contextualiser la Bible. Donc quand je suis ancré dans ma culture, quand je maîtrise bien ma culture, j'ai une lecture assez euh, euh, euh, compréhensive, profonde de la Bible. Donc moi je veux plutôt renverser la flèche en partant de la culture africaine vers la Bible."

$6 \mathrm{P}_{5}, 210-212$ : “[...]Or, si vous regardez nos pères, les, les, les euh Saint Augustin, Origène voilà Origène l'Egyptien, vous verrez que naturellement, dans leur théologie, ces gars sont ancrés dans leur culture."

7 According to http://www.brittanica.com (accessed on 15.06.2017) Pan-Africanism is "the idea that peoples of African descent have common interests and should be unified. Historically, Pan-Africanism has often taken the shape of a political or cultural movement." 
from Abidjan the Pan-Africanist arguments play a more substantial role which we will elaborate on below. Although Patrick does not identify himself as a Pan-Africanist, he is clearly interested in this intellectual position and thinks that it would be possible to reconcile the Pan-Africanist and Christian understandings of science. ${ }^{8}$

This does not imply that these participants deny the difficulties of reconciling African cultures and the Biblical perspective. In fact, they mention the incompatibilities between their cultures and some basic Christian understandings. Nevertheless, they underline the positive contribution of African cultures to understanding the Bible. In support of this, Junior, a Lutheran law student, highlights the fact that faith in God and sacrifices in African cultures positively predispose most Africans to the Christian faith. ${ }^{9}$

This appreciation of their African cultures includes a positive understanding of what they call traditional knowledge and science. Brice talks about the science and knowledge promoted among his people: "We are very good at physiotherapy. There are professional therapists that give you treatment when you have a crushed bone. They use different plants and the massages will bring together the parts of the bone. Within some weeks you are on your feet again." It is very interesting that before speaking about this science, Brice mentions that in his culture it is acceptable for Christians to make use of traditional practices when they do no harm to others. For example, according to him, going to a marabout ${ }^{10}$ is not considered a problem for Christians if they are in need of protection or natural medicine. ${ }^{11}$ Junior provides another example of

$8 \quad$ P19, $39:$ : [...] Et à ce niveau cela me semble vrai parce que ça permet de concilier à la fois la condition et l'intellectuel panafricain ou panafricaniste, de l'intellectuel chrétien vis-àvis de la science, c'est-à-dire que ça me permet de voir peut-être une possible opposition des intellectuels qui sont attachés à la fois à leur culture, à leur foi et prennent la science pour se hisser et influencer la société. Voilà la position qui se voit à partir de ce modèle. [...]."

$9 \quad \mathrm{P}_{3}, 177$ : “[...] La majorité, je veux dire $(\mathrm{xxx})$ toutes les cultures africaines en général reconnaissent quand même qu'il y a un Dieu qui existe, il y a un Dieu qui existe, un être au-dessus de tout, contrairement à d'autres qui pensent que non, ce Dieu là n'existe pas, l'homme lui-même peut être son Dieu. Ça, ça prédispose les Africains à croire."

10 Marabout, a word used in Muslim countries in Africa to indicate a (Muslim) traditional healer. The North of Cameroon is also prominently Muslim, so it is understandable that Brice uses this term.

11 P16, 67: "[...] Il y a ce qu'on appelle chez nous la notion du mal. Quand ce que tu fais, la pratique traditionnelle que tu peux faire ne fait de mal à quelqu'un d'autre, il n'y a pas de problème. Ça veut dire que tu peux de, tu peux t'appuyer sur la coutume, la tradition donc pour te protéger et du moment où tu ne fais pas de mal à quelqu'un, il n'y a pas vraiment de problème. [...]Tu peux trouver quelqu'un qui est chrétien mais s'il part chez le marabout pas pour tuer quelqu'un ou pas pour faire du mal à quelqu'un, c'est pour se protéger, il dit que non bon j'ai utilisé tel médicament ça vient de la nature. Du moment où c'est pas pour tuer quelqu'un, il n'y a pas il n'y a pas de problème. Et en parlant de science même 
this positive view of traditional knowledge when he lauds the medical knowledge of his people, and points to the mathematical insights that are acquired and transmitted by playing cultural games. ${ }^{12}$

The second subgroup stresses the non-Christian character of traditional cultures slightly more. This does not mean that they reject traditional culture completely, but to them a critical approach seems the most sensible for Christians. ${ }^{13}$ Loïc, a student of health sciences, and Enow, the Baptist theologian, are actively involved in the debate. They successfully protest against a positive role of culture in the reception of the Bible as proposed by Brice. In fact, Enow argues in the opposite direction to Brice: "I would say that the better I know the Bible, the more I comprehend my culture."14 Indeed, Loïc goes as far as to argue that "our [African] cultures don't give us a good understanding of the Bible."15 These voices become prominent in the group. ${ }^{16}$ The dominance of the second subgroup, as expressed in the model, and supported by what we call 'the rest', shows the doubts of the majority regarding what is argued by those who advocate a more positive perspective concerning the contribution of African culture to Christian faith. Most of the participants do not feel comfortable with

rapidement, chez nous il y a nous sommes très forts en kinésithérapie. Il y a des masseurs euh professionnels où, tu peux avoir ton... os broyé, il y a des plantes là qu'ils mélangent et ils massent et les bouts des... os viennent se converger ensemble et ça prend en quelques semaines tu es tu es debout. Donc euh... même quand on se convertit chez nous, bon c'est pas mon cas hein, il y a des choses que je ne fais plus. Mais quand tu pars au village, les gens partent à l'église. Bon ils font leurs pratiques du moment où ça ne fait pas de mal à quelqu'un, il n'a pas de problème."

12 P16, 124 : "Oui, il y a des gens spécialisés dans la médecine (rires et murmures) et il n’y a pas que ça, l'utilisation des écorces pour guérir certaines maladies, c'est tellement poussé. [...] Ceux du grand nord savent que, il y a même beaucoup de mes frères qui font les mathématiques en langue Toupouri. Parce qu'il y a les jeux, certains jeux chez nous, c'est vraiment les jeux hautement euh mathématiques."

13 P13, 145, Enow : “[...]Voilà, et je voudrais parce que c'est un des thèmes vraiment importants qui a préoccupé les théologies africaines dans ces dernières années. Bon, de montrer que bon notre culture n'était pas forcément, euh totalement en contradiction avec la foi. [...]."

$14 \mathrm{P}_{5}, 180$ : "Moi je disais que mieux je connais la Bible, plus je comprends ma culture, plus je m'insère dans ma culture."

$15 \mathrm{P}_{5}, 195:$ : “...]Nos cultures ne nous donnent pas d'avoir une bonne compréhension de la Bible. [...]."

16 This is visualized in the model, see figure YS2. The arrow between 'African culture' and 'Bible' that is put into place after Brice's proposal does not fit into a longer feedback-loop and its meaning is therefore very limited. In contrast, the arrows between 'Bible' and 'African culture' are dominant elements in the two feedback-loops of the cluster; especially in relation to the variable 'domain of study'. 
this understanding. Finally, this viewpoint is given a theological foundation. In the final session in November 2016, Enow makes an interesting contribution by stating that the Bible criticizes all cultures. Thus, Enow argues that what was visualized in the model about the relationship between the Bible and African cultures, is also true for European cultures. ${ }^{17}$

\subsubsection{Creating an Intercultural Space}

The debate about culture in the student group is strongly focused on the African situation and African cultures. However, the African context and traditions are not perceived as the only relevant cultural forces. While focusing on the African situation, European or Western culture is also addressed, although not always explicitly. In the first session, Western culture already has an interesting role; during this session, the students agree that science can contribute to the flourishing of faith, but they also recognize a factor that hinders this contribution. ${ }^{18}$ The so called 'common use of science' often provokes problems for faith. In the next chapter we will investigate this more closely. This unease with science appears to be a counterpart to the unease with African culture when it comes to faith. In the second session, the participants relate the problematic aspect of science in relation to faith to its Western or colonial background. In this context, the expression 'white man' is used. For example, Esek, a Roman Catholic student of urban planning, uses the expression "who lives as a white man," to distinguish between an academically schooled person with a good job in Yaoundé, and people of the same ethnicity in the villages. ${ }^{19}$ This implies a

17 P19, 31 : ‘[...] Je veux dire que ce n'est pas seulement propre à l'Afrique, même la Bible a aussi frontalement attaqué les cultures des autres peuples, de tout le monde, même les Juifs, même les Européens, pour dire que ça ne doit pas nous scandaliser qu'on dise que le message qui est prôné d'une certaine façon amène les hommes à vivre justement dans une certaine 'libertique(?)' qui les pousse à s'affranchir justement et qui créé une tension avec leur culture originelle. Bon je ne vois pas pourquoi ça changerait, ce circuit à mon avis me parait tout à fait euh, qui tient, logique, et il tient vraiment, il y a ce rapport conflictuel entre la bible et la culture africaine qui peut être positif dans un sens que on s'identifie mieux à certaines pratiques et tout. [...]'.

18 See figure YS2. On the left-hand side of the model the variable 'domain of study' is linked to 'flourishing of faith' by four arrows that create two connections between these variables. It is the variable 'common use of science' that indicates the complicating factor when it comes to science's contribution to the flourishing of faith.

19 P16, 22 : 'Bon la connaissance et la science, euh je crois que enfin ce que j’ai observé c'est que euh quand quelqu'un a beaucoup étudié, quand quelqu'un a beaucoup étudié, on ne on sait presque d'emblée que les choses qui concernent la culture là, il a tendance à négliger ça, il ne s'intéresse pas trop à ça, donc on ne va lui parler de ça que si euh il vient luimême chercher, c'est si lui-même il demande, je sais pas, si quelqu'un qui a un poste ici à 
very close relation between science and the Western world. Patrick confirms this use of 'white' when he traces the expression 'white wizard' back to its use by his people (the Tuki from the centre of the Country) to express their respect for westerners and their science. ${ }^{20}$ Janvier is more explicit about the unease that is associated with science. He explains that although his people, the Bamileke, have a positive understanding of education and science, there is also a degree of distrust because of the link between science and European colonization. ${ }^{21}$ This link between unease about science and European usurpation is confirmed by Brice during the last research session. He argues that the distrust of science in (African) culture is caused by the idea that science is something of 'les blancs' (the white people). In his understanding, this distrust neglects the proper African contributions to science and faith. ${ }^{22}$ Furthermore, Loïc objects to the distinction between 'African culture' and 'science' that the group has pinned down in the model. He argues that 'science' is also culturally

Yaoundé rentre au village et qui demande peut être de la protection $(\mathrm{xxx})$, c'est là où les villageois vont vraiment s'acquérir, mais si il ne demande pas, en général, on le voit comme quelqu'un qui n'est plus vraiment attaché à son village, qui qui vit comme les blancs $(\mathrm{xxx})$, donc on ne l'identifie plus vraiment à tellement au peuple, sauf si il demande quelque chose, c'est là où maintenant on va l'orienter.

$20 \mathrm{P} 16,50:$ : $[\ldots]$ la culture Tuki encourage, encourage l'école parce que euh euh cette culture n'est pas un peu comme celle de l'Ouest (xxx) mais c'est une culture qui est proche quand même, qui a eu des contacts avec les blancs. Or le Tuki a vu le blanc comme étant un modèle parce que le blanc il connaissait tout, le sorcier blanc c'est comme cela qu'on l'appelait chez nous. C'est un sorcier et il connait beaucoup de choses du point de vue intellectuel, du point de vue, du point de vue, du point de vue et naturellement on dit on encourage les enfants de chez à devenir comme des blancs, à connaitre l'école et connaitre l'école c'est connaitre la science. Donc la culture Tuki n'est pas antinomique euh n'est pas antinomique à la science."

21 P16, 42 : “[...]L'éducation au départ dans ma tradition était une chose dont il fallait se méfier. Il faut aussi dire que l'Ouest du Cameroun c'est à l'intérieur du pays. Et l'Ouest fait partie des régions du pays qui ont été trop tard en relation avec la science même venue de l'occident. Bon au départ $(\mathrm{xxx})$ je le dis parce qu'il y a des études qui en parlent. L'Ouest aussi s'est méfié pendant longtemps de l'occident parce que c'est l'un des peuples qui a subi un peu les affres de la colonisation. [...]."

22 P19, 51 : “[...] Donc je crois que le problème c'est que on fait souvent cette opposition entre la science perçue comme étant la chose des blancs. C'est comme s'ils sont venus avec, alors que nous on avait déjà notre science à ce niveau. Donc en parlant du concept de la culture, dans la culture africaine il y a la foi et la science. C'est vrai que je n'ai pas relevé les éléments de la foi. Je prends aussi le concept de la foi, l'intervenant d'hier, le docteur Yaoudam a évoqué cela. Que même dans notre tradition, il y a l'idée d'un être suprême et à travers les mythes et les contes, on nous ramène aussi vers cette idée de cet être suprême, donc la culture africaine en elle-même c'est un tout, ça inclut la science et la foi." 
linked and should therefore be called 'European science' while 'African culture' has its own science. ${ }^{23}$ It follows a certain logic that those who advocated for a more harmonious understanding of African culture and the Bible (Brice, Loïc, Patrick, and others) are also those who view the Western character of science as problematic.

However, this cultural understanding of science resounds more broadly in the group. While faith is regarded as deeply embedded in culture, science is also believed to be strongly linked to culture. The group generally agrees that although science often presents itself as culturally neutral (at university for example), it is profoundly European and colonial. By focusing on African cultures and traditions and addressing the Western (colonial) character of science, the two major themes discussed in the debate (faith and science) are placed in the intercultural space in which the participants live. Both African traditions and cultures, and Western (post-) colonial influences are brought together here. Finally, we note that the Christian faith and the Bible also influence this space; their specific role is studied in the third part of this chapter.

\subsubsection{The Academics from Yaoundé on 'African' and 'Western'}

Although a similar process to that of the students can be recognized in the debates of the academics from Yaoundé, this only came to light in the second research session. The first session with the Yaoundé academics was quite different to that of the students. Instead of two opposing groups, there is a natural leader, Martha, who gently guides the group, particularly during the process of model building. She is a professor in urban studies, with a Pentecostal background and a lot of administrative experience at the university. Lamentably, there was much more variance in participation here and the composition of the group changed over time. Thankfully, slightly more academics participated in the focus group sessions.

Nevertheless, a certain degree of continuity was guaranteed thanks to the continued participation of three persons who also took part in the first session.

23 P19, 77 : “[...] Parce que je ne conçois pas euh le terme, on dit culture africaine, mais quand on veut parler de culture européenne on dit la science. (murmure) Parce qu'en réalité, ce qu'on appelle science là, c'est la culture européenne et ce qu'on appelle culture africaine, c'est notre science africaine. Et moi je pense que la mort de la science africaine ou bien euh, (murmure) du moins je reprends un peu un terme qui a été utilisé, c'est une réalité parce que si aujourd'hui un tradipraticien ou bien un parent qui connait bien traiter, qui connait bien masser, on ne peut plus avoir de kinésie thérapeute chez nous, dans notre culture, c'est parce que quelque part les blancs sont venus avec la foi. [...]." 
In general, the group was characterized by a strong presence of natural scientists (Physics, Chemistry, and Medicine).

The content of the first research session with the academics goes in a different direction to the development in the student group in that no substantial mention of African or European culture is made. In the next chapter we will investigate this group's very positive understanding of the contribution of science to faith. 'Science as a place of revelation' is probably the most affirmative qualification of science used in the first session. However, in the second session, a cultural analysis appears inevitable for the group. Starting with the case of the doctor at the hospital, who prays with her patients when the medical diagnosis does not lead to a clear answer (see Chapter 2 for an explanation of the function of this case in the second research session), several affirmative remarks are made about African culture. ${ }^{24}$ In addition to approving this holistic approach, Tabot, a Protestant-evangelical mathematician, approves of the 'traditional science' of using plants to treat illnesses. ${ }^{25}$ However, Félix, a professor of medicine, also talks about the clash between traditional African science and what he calls ("excusez-moi") "Western science." He says that while the latter can be verified and is taught in school, the former cannot and is passed on from person to person. When asked to explain, Félix says that some of the traditional understanding about plants and their medical uses appears to be correct, so there is some accurate medical knowledge in traditional cultural ways. However, he says that the knowledge has not been formally verified but is simply accepted and passed on by tradition. ${ }^{26}$ Ayuk, a young computer

24 See Chapter 2 for a further explanation regarding the use of the doctor's case in the second research session.

25 P15, 220. Tabot argues: “[...] Comment est-ce que nous on fait dans notre tradition quand quelqu'un est peut être malade ? Je crois que nous, on se réfère euh aux plantes, aux plantes, c'est pourquoi il y a peut-être même certaines maladies comme par exemple la typhoïde. Tout le monde au quartier a tendance à dire que non, vraiment à l'hôpital là, on ne trouve pas vraiment une bonne solution. Il faut que tu ailles te faire traiter avec les, les plantes d'habitudes pour la typhoïde, donc de plus en plus dans notre tradition, je crois que peut-être ça peut même être général, donc on a tendance beaucoup plus à utiliser les plantes de prime à bord. Et puis bon avec la médecine maintenant, bon les choses aussi ont peut-être se sont améliorées pour certaines maladies ; mais d'autres aussi parce qu'il y a beaucoup de maladies que certaines plantes donnent quand même de solutions acceptables ou même des guérisons si je peux le dire ainsi." See also P15, 124-126.

26 P15, 228: “[...] Il y a une plante ici au Cameroun avec un coté vert rouge, (murmures) on dit que ça donne du sang. Bon quelque part c'est une vérité pourquoi, parce qu'effectivement quand on a pris cette plante, on a fait des études au laboratoire on s'est rendu compte que cette plante contient du fer n'est-ce pas, mais mais mais la teneur en fer est maximale pendant la saison pluvieuse, pendant la saison sèche il y a aucun fer dedans. Vous 
scientist from Douala who did not participate in the first research session, fiercely opposes the way Félix compares African and Western science. He believes that one cannot talk about Western science without mentioning colonisation, which prevented the development of African science. As a result, in modern day Cameroon many people have an ambivalent appreciation of Western science. He therefore argues that traditional knowledge (he prefers the word 'savoir' instead of 'science') should be held in higher regard, taking it more seriously than Félix does. ${ }^{27}$ The controversy becomes even more pronounced when Martha joins in. She has a very different understanding, believing that a lot of traditional knowledge and rites are directly opposed to Christian faith. "The values that are transmitted through traditional rites can absolutely not contribute to the flourishing of Christian faith." ${ }^{28}$ She argues that these rites are sometimes the fruit of colonial times, (as is the case for traditional funerals and the cult of the skull) making them less 'traditional' than most people suppose, and, in her understanding, profoundly satanic. ${ }^{29}$

comprenez ça c'est un truc, ça c'est un truc; donc c'est pour dire que la science africaine quelque part elle est comme ça. (murmures) Il y a des choses vraies, il y a des choses qui quand on entre en profondeur ce n'est pas tellement ça. Je prends l'exemple d'autres plantes là, on a fait cette étude, effectivement les gens quand ils sont anémiés, ils prennent cela ils boivent, mais le problème c'est que, comme c'est, comme c'est aveugle on ne sait pas, bon celui qui prend en saison pluvieuse par exemple, (murmures) il se sent, ça va marcher, il va peut-être en faire, il va faire de ça une théorie, ce qui n'est pas vrai. [...]donc c'est pour dire que la science africaine elle est, dans notre tradition, c'est des choses qui ne sont pas vérifiables ils n'ont pas vérifié, c'est des assertions qu'on fait tout simplement."

27 P15, 230 : “[...] Je suis pas du tout d'accord ! (rires) pas du tout! Pas du tout! Pas du tout! Pas du tout d'accord [...] on ne peut pas envisager la science venue dans un contexte de colonisation avec les traditions africaines sans évoquer la colonisation. Parce que la colonisation est venue nier un savoir africain, dire vous ne savez rien, euh et on vous civilise, c'est-à-dire qu'on vous civilise, on vous apprend à porter nos vêtements, parler notre langue, et raisonner comme nous! On ne peut pas parler de notre tradition aujourd'hui sans évoquer ça. Ça fait comme qu'il y a, comme une situation de méfiance vis-à-vis de quelque chose qui a été imposée ; donc c'est la réalité, la preuve c'est que parfois on s'extasie quand on voit l'avion passer on dit que waouh! On dit la sorcellerie est fort, mais parfois quand ça touche, parce que c'est extérieur, quand ça touche à la santé ou au corps, on dit non non non non non! Donc les traditions africaines ont ces doubles attitudes, parfois on est ouvert parce qu'on a perdu beaucoup de choses, parfois aussi on est méfiant parce que ça a été un peu comme imposé."

$28 \quad P_{15}, 254$ : "Les valeurs qui sont transmises par les rites ne peuvent en aucun cas, apporter l'épanouissement de la foi chrétienne."

29 P15, $225:$ : [...]Donc de la même manière que on ne peut pas dire le mot vilebre vilebrequin (rires) dans ma langue parce que c'est, c'est on ne connaissait pas le véhicule, donc ça n'a pas de correspondant. Donc le terme science dans ma langue déjà ça on ne connait pas. Et il y a deux il y a la principale notion c'est la sorcellerie, ça veut dire que quand on 
In contrast to the first session, the debate at the end of the second session is very focused on the cultural differences between 'African' and 'Western'. Ayuk's response to Félix, and Martha's reaction, show that the relationship between African culture and Christian faith was a central part of the academic group, just as it was in the student group. It is noteworthy that Ayuk is younger than the other participants and this could point towards the importance of a generational difference. Ayuk's very positive attitude towards traditional knowledge, and his expression, "I do not think that any knowledge poses a problem for faith,"30 sounds similar to the perspective held by Brice, as expressed during the student sessions. This possible generational difference will be further analysed in Chapter 5. Between the extremities of Martha's and Ayuk's positions there are a diverse range of perspectives held by the other participants, such as the more nuanced perspective of Félix. It appears that Ayuk's more radical view, that considers science to be closely related to colonialism and defends a proper place for traditional African knowledge, was needed to reveal the hidden diversity of perspectives among the group on this point. Here, the entrance of new participants (among them Ayuk) leads to a deeper understanding of the discourse. However, Ayuk does not convince the majority of participants. In general, the academics believe traditional knowledge to be part of a nonChristian perception of the world that can easily prevent the flourishing of Christian faith. However, they do not deny the value of certain aspects of traditional knowledge. Although the group does not support Ayuk's (dis)qualification of western science as colonial, Félix' reaction shows that when it comes to concrete scientific practices the use of the cultural qualification 'Western' for science appears to be inevitable.

In the last focus group session, the academic group again received new participants, and thus new input, for the final, evaluative meeting of the third research session in November 2016. Due to the new participants, different aspects of the model were questioned and critically approached, however, the

ne peut pas expliquer quelque chose, quand on ne comprend pas quelque chose, automatiquement ça relève du surnaturel, ça relève oui, ça relève du surnaturel." And more explicit in $\mathrm{P}_{15}, 257$ : “[...] Il faut d'abord comprendre pourquoi on a commencé les funérailles avec, ça n'a, ce n'était pas la tradition, ça a commencé avec la colonisation, ça a commencé avec la colonisation.[...]Et à l'occasion, on va retirer son crâne, on va embaumer et on va aller mettre dans la maison sacrée, on va préparer un mets, on ne met pas le sel et chacun va mettre sa main comme ça, comme ça là on va lui donner et on va aller donner pour le crane à l'intérieur. Le lendemain maintenant quand on fait les célébrations, il y a une phase à l'intérieur qui est satanique, quand on fait les tours là, il y a un nombre précis de tours qu'on doit faire. Et ces tours là c'est à la gloire de satan. [...]."

$30 \quad P_{15}, 73:$ : '...] Mais je ne pense pas que fondamentalement la connaissance, toutes les connaissances, je ne pense pas qu'elles soient un problème pour la foi. [...]'. 
cultural aspect was not really discussed. This is understandable because the discussion was based on the model and culture is not included in the academics' model. However, Tabot repeats the general feeling of 'the group' (that is the group of the second session) by saying that the relationship between traditional culture and Christian faith provokes tensions and problems.

1.1.4

Conclusion Concerning the Discourses of the Two Groups from Yaoundé

In the end there is more similarity between the discourses from Yaounde than we expected. The second session among the academics is strongly focused on the contribution of African traditions to science and shows that it took just a small step to a theological evaluation of these traditions. Martha resists Ayuk's positive perspective regarding these traditional practices because she qualifies them as satanic - at least when it comes to her own Bamileke background. ${ }^{31}$ Above we pointed out the correlated differences between Brice and Patrick on the one hand, and Enow, Loïc, and Janvier on the other. This provides us with greater clarity about the two tendencies in both groups. The first is inclined toward a positive and constructive understanding of the contribution of African cultures to the science and faith debate. This perspective is openly defended by students such as Brice and Patrick, and by academics such as Ayuk. However, this constructive outlook is challenged by a position that leans toward a more critical understanding of African cultures which is expressed moderately by students such as Loïc and Enow, and, most outspokenly by Martha in the group of academics.

The main tensions in both groups are related to the difference between these two tendencies and address the question of whether African culture and/or traditions can be included in science and faith. It appears that those who are against, or hesitant about, the inclusion of African traditions perceive these cultures and traditions to be incompatible with Christian faith. They fear that they will limit the liberating power of Christian faith (several students) or even increase satanic power (Martha). Prioritising Christian faith brings these participants into conflict with, or makes them hesitant to affirm, Africanculture; specifically its religious character. The other tendency departs from the idea that the African understandings of science and faith must be integrated because of the unity of life. Thus, African traditions and cultures are not

31 That Martha uses a strong term like satanic is probably related to her Pentecostal background (Bom 2019). 
perceived as a threat to faith or science, but rather as necessary elements that make vital contributions in these areas.

However, the debates show that these different perspectives provoke a dynamic process that establishes the framework for forming beliefs about science and faith. The critical view regarding African traditional knowledge and science, as expressed by Martha, Loïc, and others, is, in a way, reflected in the critical view of Western science held by people such as Brice and Ayuk. In the same way, the positive perspective on (Western) science put forward by Martha and Félix is mirrored in the positive evaluation of African science by Brice and Ayuk. As one of the moderate participants, it is Félix's apology (for using the term 'Western science') that highlights the inevitability of an intercultural understanding of science and faith in both groups. This understanding is directly related to their (inter)cultural location at a crossroad where African traditions, Christian faith, and Western science all meet.

We label this dynamic and intentional process 'intercultural framing'. Although we did not find specific uses of this term in the literature, the phenomenon can be identified in other fields. For example, the active and deliberate managing of culturally diverse perspectives can be recognized in the academic field of policy making, as described by Zapata-Barrero (2016) and others. This author uses the term 'interculturalism' to indicate a policy strategy that is aimed at promoting interaction and community building between people from different backgrounds, and at reducing prejudice (Zapata-Barrero 2016, ix). However, in contrast to Zapata's interculturalism, the creation of an intercultural space in the Yaoundé groups is not orchestrated or initiated by leadership or from outside. Rather, the creation is part of a group process, which also confirms our preference for a group research tool. Davis and Russ, who studied the communication between scientists, educators, journalists, and the general public, help us to be even more precise. These authors focus on the change of scientific knowledge through communication and point out the importance of 'sense making' among all those involved. They also highlight the central role of framing, which is understood as "a set of simple elements that organize the perception of a given situation" (Davis and Russ 2016, 223). More specifically, they state that: "In this science education research, framing is understood to be a dynamic process that 'depends on input from the physical world, from culture, and from social interactions." Davis and Russ' research underlines the dynamic aspect of this kind of framing: "Because framing grows out of the particulars of interactions between students and teachers, any changes to those interactions or the context, however slight, can produce moment-tomoment changes in the knowledge that participants bring to bear in the interaction (i.e. their framing)" (Davis and Russ 2016, 228). This understanding fits 
the dynamic process that took place in the Yaoundé groups, and thus 'intercultural framing' seems an appropriate term to use. In this book, we therefore define intercultural framing as a dynamic and intentional way of making sense of a subject or theme (in this case science and faith) by relating it to varying cultural conceptions of this subject or theme. In what follows we will explore whether intercultural framing also occurs in the groups from Abidjan and Kinshasa.

\subsection{Abidjan}

The discussions in the two Abidjan groups developed quite differently than the debates in the Yaoundé groups. However, the recent unrest in the city, and more specifically on the campus just a few weeks before the first research sessions took place, appears to function as a specific hermeneutical key for the participants in both groups. The violence is in keeping with the recent pattern of violence in Ivory Coast (see Chapter 3), and therefore both the students and younger academics are considered to have been raised in a politically unstable and vulnerable situation.

1.2.1

The Struggle of the Students from Abidjan Concerning 'Western' and 'African'

First, we focus on the student discourse as we did in the case of Yaoundé. In this group from Abidjan the communication during the sessions was very straight forward. For example, Princesse asked the facilitator for considerably more time to share and explain her standpoint, which was quite unusual in the groups. Women participated far more actively than in Yaoundé, which was partly due to the higher turnout of female respondents than in Cameroon. However, other participants were very timid, such as the student with an eyecatching green shirt who sat to the left of the facilitator; it was a real challenge to get her to talk. During the first research session, the three-hour debate was very lively containing sharp remarks and responses, laughter, and comments all made in a good atmosphere. And, eventually, even the shy participants such as the girl with the green shirt made their contributions.

Lamentably, the participation of the group changed over time. Only four participants from the first session turned up for the second research session in October 2015, and we had to add two new participants in order to attain the required minimum of six. Participation was only slightly better during the third session in October 2016, when five participants from the first session appeared. The group also lacked diversity in terms of academic disciplines since most of the students had a background in the humanities (law, philosophy, history, and languages). 
During the first session, one of the main questions in the group is whether there should be just one general term for all kinds of knowledge. In the thick of the debate, the issue of 'insecurity at the university' surfaces and appears to be a difficult one to tackle. ${ }^{32}$ Someone says this variable is irrelevant, because there is no structural relation between scientific work and this (political) violence. However, Emmanuel a philosophy student with a Protestant-evangelical background who originates from the western part of the country argues that this issue is not only related to the very recent student strikes, but actually exemplifies the culture of violence at Ivorian universities: you can "be threatened" or "thrown out." ${ }^{33}$ Eventually the group decides to maintain 'insecurity' as an essential element of the model because it appears to symbolize the role of the abuse of power. This variable appears to be a crucial element of the students' model of how to deal with the cultural diversity of 'African' and 'Western' in relation to science and faith.

During this session the discourse is not focussed on the cultural differences between Africa and the West, as was the case with the Yaoundé students. Nadège, a Roman Catholic student of Law who originates from the western side of the country, plays a very central role in the final stage of the first session when the students agree on their shared understanding of science and faith. Along with Fabrice (a sociology student) and Princesse (a music student who comes from the border region with Ghana) Nadège argues that 'general knowledge' would make it impossible to distinguish between science and faith. ${ }^{34}$ However, she argues that when the idea of general knowledge is left out, the understanding of the relation between 'knowledge of faith' and 'knowledge of the domain of study' becomes uncertain. There is a broad consensus that these two types of knowledge are complementary. Thus, Nadège and others reorganise the model and place 'truth' in a central position, whereby both types of knowledge evolve out of truth and both types of knowledge are also related to the variable 'insecurity at the university'. ${ }^{35}$ In terms of the created model, both types of knowledge are placed in parallel which establishes that they both share a positive dependence on 'truth'. The relation between these two types of

$32 \quad$ See P1 293-371.

$33 \mathrm{P} 1,344$ : “Et puis l'insécurité physique, c'est pas forcément on peut te taper hein? Quand tu ne maîtrise pas tes cours, c'est que tu peux être renvoyé. C'est une insécurité. (rires) Oui, oui, oui. Et tu es menacé (xxx) bien sûr parce que ça se vit à l'université. Ça se vit, c'est pas forcément agression $(\mathrm{xxx})$ physique - là, [...] Donc ce qu'on est en train de dire ici, ce n'est pas, ce n'est pas forcément que quelqu'un vienne te battre ou te faire ci ou te faire ça mais c'est une disposition...."

34 See $\mathrm{P} 1,419-436$.

$35 \quad \mathrm{P}_{1}, 535$. 
knowledge and the variable 'insecurity at the university' is negative. This is in the sense that the growth of knowledge is supposed to diminish the insecurity, and the insecurity negatively influences the growth of the acquisition of knowledge. ${ }^{36}$

The relation between science and the abuse of power is confirmed and clarified in the second research session, when the participants are asked to analyse the influence of their traditional backgrounds on the model. They all live in Abidjan, the economic centre but are well acquainted with their original cultural backgrounds. Most of them speak their traditional language, although their knowledge and appreciation of their cultures differs. Their ethnic identification does not lead to opposing perspectives as is the case in the Yaoundé groups. Instead, when discussing the influence of cultural traditions on the model, the students pay special attention to the role of secret knowledge, referring to initiation rites that some of them have participated in. ${ }^{37}$ Stories are told about family members who wanted them to undergo these initiation rites, but who were opposed by the participants' parents (both Christian and Muslim) because of their faith. Adama, a Protestant-evangelical law student, shares about how his grandfather, a community leader and famous hunter, made him acquainted with some of these practices when Adama visited his family in the village. Upon returning home, Adama's father was furious about this and confronted the grandfather. He told him that he was responsible for his son and that he wanted to give him a Christian education. ${ }^{38}$ In this context, Aristide (a student of economics from the northern region of the country) emphasizes that from a traditional perspective academic knowledge is seen as an obstacle because of its relation to colonialism, and is thus perceived as a white men's

36 See especially the debate in $\mathrm{P} \mathbf{1}, 529-535$. For the model of the students in Abidjan, see figure AS2.

37 See P8, 119, 130, etc.

$38 \quad$ P8, 87 : "[...] Je suis le fils ainé de papa. Lorsque j’arrive au village mon grand dit : toi ton père il est perdu $(\mathrm{xxx})$ pasteur. Toi tu es notre ainé quand on regarde dans l'arbre généalogique comme ton père est pasteur, c'est c'est toi normalement si tout était respecté, s'il n'y avait pas la colonisation, tu devais être sur le trône des trucs et tout ça (xxx) la lignée. Donc toi on doit on doit t'initier. On doit, on doit on doit te mettre dans le bain parce que demain c'est toi qui doit assurer la marche de la cité, du village. Comme ça donc au village, on a commencé à faire des choses, papa n'était pas au courant, il m’a donné des pulls, beaucoup de choses et quand je suis arrivé en ville, j’avais mis ça dans mon sac. [...]Voilà donc, il m'a il m'a, il a il a commencé à me donner les trucs des initiations. Quand jeétais arrivé à la maison en ville quand papa a découvert, la même nuit il est allé au village, pour dire à papa, à son papa que lui c'est mon fils et ce que moi je lui inculque comme éducation qu'il doit suivre, on a mis un trait sur la tradition en suivant en suivant les préceptes de la Bible et autre. [...]." 
affair. ${ }^{39}$ Here a relation between science and politics is established, and a more explicit link to European power and the use of violence (colonialization) is implied. Others confirm that opposition to the knowledge of a field of study is more substantial from traditional cultures than in churches.

In this context, Emmanuel gains new insight when he tries to understand the model built from a traditional perspective. This leads him to a deeper understanding of the opposing nature of traditional knowledge and academic scientific knowledge, and their relation to power. He underscores that the distinction between the two types of knowledge in the model has a parallel in the distinction between open and secret knowledge in traditional culture. "The mystical esoteric knowledge...has nothing to do with the knowledge of the field of study'" ${ }^{40}$ The two types of knowledge now receive a cultural label; the knowledge of the domain of study becomes 'Western' and the knowledge of faith (including the "mystical knowledge") 'African'. This could have been the start of the intercultural framing we addressed in the discourses from Yaoundé, but the discourse did not develop further in this direction. According to the participants, from a traditional point of view, it is fundamental that these two types of knowledge are neither mixed nor confused. In the next chapter we will see that this perspective, believed by the students to be shared by many church leaders, comes very close to the way science and faith are handled by laïcité. Emmanuel's observation becomes clearer when compared with Beryl Bellman's interpretation of secret societies in Liberia. The author argues that the secrecy of this traditional knowledge is not related to the content (which is known by people outside the group of initiated members), but to the social distinctions within a community. When it comes to the content, he argues that secret knowledge is 'empty' (Bellman 1984, 139-144). Emmanuel's understanding points to this exact social dimension: the radical openness of Western

39 P8, $159:$ : [...] Il faut dire que nous nos cultures ont été fortement marquées par la colonisation (hum) donc ce qui est académique est vu comme euh un blocage, parce que la colonisation, avec euh la colonisation, les c'est les blancs qui prenaient les gens pour leur faire subir un certain nombre de choses, donc quand quelqu'un partait à l'école c'est comme s'il était en train de trahir la société il était en train d'aller dans la dans la société de $(\mathrm{xxx})$ au point où des gens ont fait des sacrifices pour ne pas que leurs enfants réussissent à l'école. Parce que réussir à l'école c'est un facteur d'échec pour nos pour nos parents, parce que c'est prendre la culture de l'autre pour envoyer chez toi, quelque chose de non droit qui va détruire la lignée et même tout ce qu'on voit aujourd'hui, que je ne peux pas porter de masque et c'est tout ça. Ils disent que c'est parce que les gens sont allés ailleurs qu'ils ont vu ailleurs et ils ont adopté ça. [...]."

40 P8, $119:$ : "...] le savoir mystique ésotérique est à part, n’a rien à voir avec le savoir la connaissance du domaine d'étude." 
scientific knowledge is at odds with the authority structure of the traditional African community that dominates knowledge. Traditional knowledge is not freely accessible and depends on social (power) structures. According to Emmanuel, Western scientific knowledge challenges this structure through its openness and is therefore a threat to traditional society. Here, science is again understood to be at the centre of discordant powers (Western and traditional African) which leads to (possible) conflict.

Finally, during the last research session the participants evaluated their own discourse. As in Yaoundé we presented the models built by the groups from the other cities and encouraged the participants to look for convergences and divergences. Both the student and academic groups in Abidjan are impressed by the way most of the other groups engage with variables such as 'African culture'. Nadège opens the student session by expressing the need for more cultural awareness, however, opposition to this opinion soon surfaces. Oriane, a student of criminology, argues "I think culture should not be more important than faith... Africans have more faith in their culture than in Christian faith." ${ }^{41}$ This substantiates how culture and traditional religion are identified and perceived to be in opposition to Christian faith.

\subsubsection{The Group of Academics from Abidjan}

In comparison to the student group, the participation of the academics was more reliable during the research in Abidjan. Five of the six participants from the first session were also present at the second session. Consequently, ownership of the discourse is felt more strongly here. In terms of the participants' disciplinary backgrounds, this group was also more balanced than the student group as it had representatives of the natural sciences in the presence of a biologist and a chemist. However, in terms of the dynamics between the participants, the student group was livelier and allowed clear opposition between group members. In contrast, the academics tried to avoid such clashes. Participants' perspectives and the meaning of certain statements they make are not really questioned and are often handled with care. They search for consensus and therefore construed a far more complex model during the first session. ${ }^{42}$

Sensitivity about the insecurity at the university also comes to light in this group. Rebecca, a professor of French, relates the experience of insecurity to conflicts. This appears to be a topic that profoundly affects some of the

\footnotetext{
$41 \quad P_{17}, 25$ : “[...]..Moi je trouve que la position de la culture n'est pas au-dessus de la foi ; parce qu'il faut dire que les Africains ont plus foi en leur culture qu'en la foi chrétienne. Ils ont plus foi en leur culture [...]." 
participants. Towards the end of the first session, Stéphane, a linguist who is quite influential during the debate, reveals something of the background to this sensitivity by referring to the complex cultural situation in Ivory Coast. ${ }^{43}$ He thinks that cultural awareness automatically leads to conflict and illustrates this using the example of those who argue that all school education in the country should be carried out in the mother tongue. According to Stéphane, their argument is that "A people that does not receive knowledge in its mother tongue, cannot develop itself." 44 In the end, Stéphane explains that he is speaking about the anti-Western position of the pan- Africanists. They oppose the practice of education in French in Ivory Coast, and claim that the translation of all educational resources, even Microsoft, is necessary for the development of the people's proper identity. According to Stéphane, these people argue that even if this translation takes fifty or a hundred years, and therefore holds them back for a long time, it will be worthwhile. ${ }^{45}$ Although Stéphane's study of African languages has made him sensitive to this argument, he clearly opposes this position believing it to be completely unrealistic. More important, however, is the fear that he and others share regarding ethnic ('cultural') conflict which provoked civil wars in the recent past and is also related to what is called 'the insecurity at the university'. The broader discussion on culture is thus closely linked to power and politics, and the words of Stéphane further explain why cultural diversity is directly related to politics and therefore also to insecurity and violence.

The question of the importance of culture to the understanding of science and faith is discussed intensively in the next sessions. Fidèle is a Protestantevangelical botanist who conducts laboratory research on plants used by traditional healers in order to identify their active substances. Fidèle thinks that traditional science and what he calls 'modern sciences' must not be separated because they are complementary. In this way, modern science takes its point of departure from traditional science. ${ }^{46}$ Stéphane and Kouassi, an educational

43 See Chapter 3.

$44 \quad \mathrm{P} 2,436$ : “[...] Aujourd'hui je vais donner l'exemple, notre culture, la prise en compte de notre culture serait qu'on dispense la connaissance scientifique dans les langues maternelles, du cycle primaire jusqu'à l'université. Parce qu'un peuple qui n’a pas, qui ne reçoit pas la connaissance dans sa langue maternelle, il ne peut pas faire de développement."

$45 \quad \mathrm{P}_{2}, 507$ : “[...] Si on devait revenir en arrière, il va falloir traduire tous les traités scientifiques dans cette langue, il va falloir traduire Microsoft dans cette langue, il va falloir tout faire l'administration dans cette langue. Donc, cette prise en compte là, ça (xxx) un conflit. Les panafricanistes disent, même si cela devrait mettre 50 ans, 100 ans, il faut le faire parce que c'est notre identité $[\ldots . .$. ."

$46 \mathrm{P} 9,76:$ : “...] On part toujours à partir de notre tradition qui n'a pas tenu compte de ce qui se passe en laboratoire qui n'a pas extrait de substance actifs, mais quand on arrive au 
psychologist who identifies himself as a Pentecostal, argue that modern science is rejected by traditional culture, because it does not respect its traditions and causes distrust. Stéphane argues that most African scientists fail to successfully integrate traditional and modern science. People get lost because "the new model ... is not completely European but more European than African, something hybrid. We are lost. See, this is the real problem." ${ }^{\prime 7}$ This corresponds to the students' analysis during the last session in which they discovered that they marginalized culture in their model. Several participants think this is typical of Ivoirians, who assimilated French culture so well. Indeed, science is seen as an important instrument in the process of assimilation. This discussion helps us to realise that this group's strategy is related to this tradition of assimilation. The strategy consists of playing down the value of African culture, because focusing on it will increase the stress on ethnic differences in Ivory Coast, which is the origin of the conflicts. However, recognition of their own assimilation as academics underlines the importance of Western, and particularly French, language and culture to academic life, (and probably more broadly the national identity) and their own identity as academics. According to Stephane, this results in hybridity and an awareness of being cut off from their roots or even 'being lost'. This awareness of their hybrid identity seems to be another reason why they prefer to avoid focus on culture. It confronts the academics with being part of a culturally lost group that is specifically oriented towards Europe (or the Western world). In a reality in which Africanists' and ethnic interests are powerfully presented their position is therefore vulnerable.

In the last session the academic group only contains three returning participants, and this adds some interesting elements to the understanding of assimilation and hybridity. The three 'original' participants, Stéphane, Kouasi, and Clément, are aware that most of the other groups paid greater attention to 'culture. Therefore, the conversation begins with a focus on culture. Yao, a new participant who is a professor of economics and an Protestant-evangelical, makes the questioning more personal by asking: "Which culture do we have? Do we have an African culture? Or do we have a Western culture? Or do we

laboratoire souvent c'est confirmé, souvent c'est confirmé. [...]Ce n'est pas dans tous les cas, c'est pas dans tous les cas ; c'est un exemple que moi j'ai pris pour dire que toujours euh souvent on a tendance à forcement séparer les deux alors qu'en réalité, les deux se complètent : la science moderne s'appuie sur la science traditionnelle pour devenir plus meilleur. [...]."

47 P9, 82 and 86 : “[...] Il n'entre nulle part parce que euh dans le nouveau modèle qu'on a, qui n'est pas totalement occidental mais qui est en fait plus occidental qu'africain, qui est hybride mais qui fait la part large à l'Occident. On ne se retrouve plus. Voilà c'est ça le véritable problème. [...]." 
have a hybrid culture?"48 The sociologist Jaures, another new and Protestantevangelical participant, believes science and faith are representative of cultures. He sees himself and his colleagues as participating in three cultures at the same time: their original culture, scientific Western culture, and Biblical culture. ${ }^{49}$ We come back to the use of hybridity in Chapters 5 and 6. Some argue that African contributions to science are frequently neglected and do not receive the attention and honour they deserve. Jaures emphasises that it is often easier for Christians, who do not believe in the traditional myths and the related spiritual powers because of their faith in Christ, to investigate phenomena that provoke fear in non-Christians because of their belief in those myths and powers. ${ }^{50}$ This is confirmed by Jacob, a professor of art and cultural development, who encourages the others to help the students. He says that he never had problems with a scientific approach. "There are no taboos for knowing [...] we are naturally predisposed to reconcile these two things [science and faith]." ${ }^{51}$ Amazingly, this perspective is almost identical to Ayuk's argument from the academic group in Yaoundé. We will analyse these words in the next chapter.

1.2 .3

Conclusion Concerning the Discourses of Both Groups from Abidjan

In the discourses of the two groups from Abidjan, the themes of 'African tradition' and 'Western (culture)' play a different role than in Yaoundé. Interestingly, a variable referring to African traditions or culture is absent from the students' model and marginalized in the academics' model. Instead, the conflict between Western and African influences is mainly concentrated in the inclusion and understanding of the variable 'insecurity at the university'. This

$48 \quad$ P18, 17 : “[...] Mais aujourd'hui, nous, quelle culture nous avons? Est-ce que nous avons la culture africaine ? Est-ce que nous avons la culture occidentale ? Ou bien est-ce que nous avons une culture qui est hybride, quel type de culture nous avons ?[...]."

49 P18, 19.

$50 \quad \mathrm{P} 18,30$.

$51 \quad$ P18, $34:$ : “...] Moi, mon expérience personnelle, c'est que je suis chrétien mais je n’ai jamais eu de problèmes pour aborder des situations du point de vue scientifique, il n'y a pas de tabous, il faut le leur dire clairement qu'il n'y a pas de tabous bien au contraire, comme il l'a dit, de façon naturelle nous sommes prédisposés à concilier les deux choses, ceci, il faut le leur expliquer. Il faudrait que notre expérience de chrétiens en même temps d'enseignants, j'allais dire d'académiciens, nous permettent donc d'aider, d'encourager de plus en plus, notre expérience personnelle doit encourager, il faut à chaque fois revenir dessus, revenir sur ce fait pour que de plus en plus les jeunes comprennent que Dieu c'est comme on dit, Dieu c'est cet être (xxx) qui est au-delà même de science, de la métaphysique. [...]." 
conflict is very concrete and refers not only to the unrest at the university during the Spring before the first research session, but also to a more general political tension in Ivory Coast, and to the influence of Pan-Africanist stances, as became particularly clear from the academics' discourse. It is evident that this concrete context provides important background information for understanding the way in which the opposing influences of 'Western' and 'African' were addressed in Abidjan. Although there are some interesting differences between the two groups from Abidjan (mainly related to a stronger identification with academic life among the academics), in both discourses the use of the terms 'Western' or even 'colonial' and 'science' does not have the same connotations as in the discourse from Yaoundé.

In the discourses from Abidjan, the use of 'African' and 'Western' is narrowly related to power and suppression. The academics' discourse reveals that their tendency to avoid giving culture a more substantial role is not only due to their fear of conflict and violence as is the case among the students but is also related to their own position as academics. In the context of ethnic and Africanist profiling, the assimilated academics (because of their direct relation to Western science) are a vulnerable group without a univocal belonging. For these reasons, the participants fail to assign culture a proper role in relation to science and faith, despite this being a desire expressed by both groups during the third research session. In the final section of this chapter we compare the dynamics of the six groups more extensively, and clarify why intercultural framing is not an appropriate term for what is going on in the groups from Abidjan.

\subsection{Kinshasa}

When we arrived at N'Djili International Airport for our GM B sessions in June 2015, we did not realise that this would be the last time we used the old buildings with their faded glory and experienced the airport's chaos of passengers and luggage. Only a few months later a brand new terminal was in use and the procedures put in place by the local authorities were much more efficient. However, navigating the old airport in June took us some time and it was late when we entered Kinshasa. At three o'clock in the morning, as we drove down the long road from the airport to our guesthouse in the city centre, there were still people walking along the highway. During the period of our research the political situation in Kinshasa was unstable, although that is a fairly normal state of affairs in the Democratic Republic of Congo.

However, in contrast to the discourses in Abidjan, the political unrest never appeared as a theme in the discourses, let alone in the models of the two research groups. Fortunately, thanks to the enormous efforts of local GBU staff and other people involved, we had no problems traveling and organising the 
meetings in 2015. However, particularly during the second half of 2016, the situation began to deteriorate further. The presidential elections scheduled for December were cancelled by the government, and this provoked unrest and protests in the streets of Kinshasa that were violently suppressed. In October, the local GBU advised us not to come, and so we postponed our visit realizing that the third research session with the groups from Kinshasa would not be possible in the time allotted for this research. We had, however, gathered enough material in the first two sessions to allow the reconstruction of the major characteristics of the discourses in both the student and academic groups.

The Kinshasa groups function as a critical case, because the Democratic Republic of Congo has not been colonized by France and therefore lacks the laïcité understanding of education as a sign of colonial heritage. ${ }^{22}$ We are curious to know if this difference in context also influences the understanding of 'African culture/traditions' and 'Western culture'. Kinshasa

The composition of the student group in Kinshasa has a strong inclination towards technical and applied sciences. Of the eleven students who participated in the first session, only a few are taking courses related to classical scientific careers such as law and medicine. The others are students of applied studies such as trade, electricity, and public works. Only four of the eleven are women. No Roman Catholic students are included and of the total thirteen participants in the two sessions, seven identify themselves as Pentecostals. It appears to be more difficult for the GBU to find enough MA students in Kinshasa so a small number of the group are what could be called BA students. Thus, in certain areas, the group is less diverse than others, and there is no doubt that its specific features have an impact on the group's discourse and the model they build. This model does not feature any epistemological terms, such as 'knowledge' and 'understanding', and specific variables such as 'technology' are added that refer to science and scientific practices. Over time the participation of this group is more stable than that of the students in Abidjan. In the second session in November 2015 half of the group from the first session was present. Thus, just two new participants came in to reinforce the group for that session.

It is only during the last thirty minutes of the first session that the participants turn to the role of 'African culture'. Staelle, a very active participant who is studying computer sciences, qualifies the relation between 'technology' and

$5^{2} \quad$ The function of Kinshasa as a critical case is explained in Chapter 2. More on the specific cultural background of Kinshasa can be found in Chapter 3 . 
'African culture' as a negative one. ${ }^{53}$ Keicha, a student of styling from a Protestant-evangelical background, agrees with her using the argument that Christian faith makes people abandon certain habits typical of African cultures. ${ }^{54}$ However, this understanding is challenged by Gloire, a Pentecostal student of medicine, who alleges that faith also contributes to culture. Here, Gloire brings in a different and much more dynamic understanding of culture than we have seen so far. According to Gloire, clothing is a good example. He says, "With Christian values, the women began to wear clothes." ${ }^{55} \mathrm{He}$ also underlines the positive contribution of African culture to faith: "African culture implies the community of brothers and this community brings forth, or stimulates, faith; it lets faith grow." 56

The role of African culture is discussed more extensively during the second research session. During this session, the students propose an alternative version of the model built in June 2015 which makes other feedback-loops possible. ${ }^{57}$ According to the students, the alternative model is necessary because the model built during the first research session could not satisfactorily handle the case of the doctor that was presented to them by the facilitator. ${ }^{58} \mathrm{In}$ both the original and the revised models 'African culture' plays a crucial role. ${ }^{59}$ However, Gloire's positive understanding of African culture's contribution to faith is still not represented in the new model. In this second session, Gloire recapitulates his defence of the possible positive influence from technology to African culture. ${ }^{60}$ This leads to a huge debate over culture, in which the new participant, Congo, a communications student and member of a so-called

$53 \quad \mathrm{P}_{3}, 427-449$.

$54 \quad \mathrm{P}_{3}, 459$ : "Parce que plus il y a la foi, il y a certaines habitudes qu'on avait dans la culture africaine qu'on ne fait plus. A l'époque, comme on dit dans la Bible, on demande de donner la dîme à l'église alors que chez nous les Africains quand tu as ce genre de truc, il faut donner au papa qui va te donner, il faut faire ceci par rapport aux parents. Alors plus on est dans la foi, on essaie un peu de bannir ces choses-là et on est plus au figé sur la Bible, on laisse tomber certaines coutumes et certains rites."

$55 \mathrm{P}_{3}, 461$ : "Moi je, je vais dans le sens contraire. Pourquoi ? Parce que la foi apporte quelque chose aussi à la culture. Je prends un exemple. Autrefois les femmes africaines étaient dénudées, elles s'habillaient pas, elles étaient pratiquement nues. Avec la foi chrétienne, avec les valeurs chrétiennes, on arrive à voir des femmes habillées, couvertes."

$56 \mathrm{P}_{3}, 553$ : "Parce que la culture africaine implique la communion fraternelle et cette communion engendre ou stimule la foi, ça augmente la foi. [...]."

57 From P10, 50 and onward, there are concrete proposals to change the model. See KS 2 and $\mathrm{KS}_{3}$ in the Annexes for figures of both models.

$5^{8}$ See Chapter 2 for the use of the case of the doctor during the second research session.

59 Also, in the revised model $\left(\mathrm{KS}_{3}\right)$, both balancing and reinforcing feedback-loops (terms explained in Chapter 2) pass through this variable.

6o See P10, 40, 42, 53 . 
(Pentecostal) église de réveil, plays an important role. He not only launches some fundamental ideas for the revision of the model, but also claims that technology as such does not destroy African culture. According to Congo, the effects of technology (and thus science) on African culture depend on the way we understand ourselves and our use of technologies:

[...] during colonial times they made us think that we were primates to be civilized; we had to rise to the level of the Westerners. That has anchored in us. The problem is not technology. I can have a telephone. However [the question is]: What does the culture inside me push me to do? It is as if I am actually moving towards the West. That is where the loss of African culture is situated. The problem is not really the technology, it is what is inside us. ${ }^{61}$

The cultural context in Kinshasa is "moving in the direction of the West," as Congo puts it, but according to the group it finds a proper balance between what could be called 'African' and 'Western'. Gloire provides a nice example of this balance when he comments on the case of the doctor using an example from his own medical studies.

I was in the hospital during my internship and we had a case of a patient with psychological problems. He suffered from a manic-depressive illness. Even in medicine they openly told us that this was also spiritual. In the treatment, a spiritual treatment should be included, and so I went out to look for a pastor. ${ }^{62}$

The specific cultural situation in Kinshasa, as explained in Chapter 3, is also discussed in this second session. In terms of the university, Gloire explains that a lot of the academics and people involved in the academic world are

$61 \quad$ P10, 59 : "[...] à l'époque de la colonisation, on nous faisait voir que nous sommes primates pour être civilisés, il faut monter dans le niveau de de des Occidentaux. Cela en ancré en nous. Le problème en réalité c'est pas la technologie. Je peux avoir un téléphone mais à quoi, la culture que j'ai en moi me pousse de faire quoi. C'est comme si maintenant j'avance vers l'Occident. C'est là où se situe la perte de la culture Africaine. Le problème ce n'est pas vraiment la technologie, mais le problème c'est ce qui est au-dedans de nous."

62 P10, $117:$ :[...] Puisque tel que je prends un exemple. J'étais à l'hôpital je suis en train de faire mon stage, on a eu un cas d'un patient, ce patient-là a les troubles psychologiques. Il souffre de d'un trouble maniaco- dépressif. Or même en médecine, on nous dit clairement que ce trouble est aussi spirituel. Dans le traitement, il faudrait adjoindre aussi un traitement spirituel. Je suis allé voir un pasteur. On s'est entendu de temps en temps prier pour la personne." 
believed to be involved with "occult lodges or occult movements." 63 This issue, concerning the relationship between the university and movements such as freemasonry and Rosicrucianism was also mentioned by students and academics from Yaoundé, and the academics from Abidjan. ${ }^{64}$ There is no doubt that this contributes to the disrepute of university campuses among (Pentecostal) Christians in Kinshasa (Pype 2012, 41). Gloire alleges that this provokes a very complex relationship with science in most Pentecostal churches. Traditionally, the leaders did not prioritize higher education, because in their view it did not improve life with God or affect going to heaven. Today, however, higher education and science are valued by most pastors and leaders. ${ }^{65}$ What makes it more complex, he argues, is the growing trend of diabolizing study on the part of certain (younger) pastors. ${ }^{66}$

In contrast to the other cities, when it comes to the different African cultural traditions, most of the participants do not have a clear image of the traditional culture they belong to and are poorly acquainted with its rituals and language. We will analyse this point in the next section of this chapter.

The Importance Assigned to 'African' and 'Western' by the Academic Group from Kinshasa

Concerning the variety of disciplines represented, the composition of the academics' group in Kinshasa is slightly more balanced than the student group, although there is also a significant participation of people from the applied sciences in the academic group. Additionally, theology and Christian philosophy are strongly represented in this group. The two Roman Catholics, two neoPentecostals, and four evangelical Protestants offer a broader Christian scope than that of the students' group. However, the complete lack of any female participation makes it exclusive in terms of gender. This was the only group in which the use of the GMB research method was challenged by the participants. Some participants thought that the method limited the group in terms of expressing themselves. They felt they were being forced into a typically Western

63 P11, 179: “Si je peux ajouter quelque chose du fait qu'il n'y ai pas une relation directe entre la foi et le domaine d'étude, c'est aussi du fait de la culture parce que dans le passé ce n'était pas seulement pour le pasteur, il y avait une, permettez-moi de l'appeler ainsi, une évangile populaire au Congo qui disait que, les gens qui étudiaient beaucoup étaient occultistes pour la plupart, la plupart des gens qui étudiaient beaucoup on disait cela, voire même on donnait à à l'université une connotation occultiste."

64 For the students from Kinshasa, see P11, 179 and 184; for the students from Yaoundé, see P 5 , 390; for the academics from Yaoundé see P15, 190; and for the academics from Abidjan, see P9, 61.

65 P11, 27: Cardin argues that there is a similar development between the generations in his neo-Pentecostal church, see P11, 56 .

P11, 276. 
understanding of science and faith. Fortunately, these worries were alleviated, ${ }^{67}$ but this sensibility is also reflected in the choice of certain variables. ${ }^{68}$

When it comes to cultural differences, Augustin, a Roman Catholic professor of Christian Philosophy, appears to be particularly sensitive to European prejudices such as the notion that all Africans are believers. He therefore wishes to include atheism and argues that this is certainly present at African universities. ${ }^{69}$ Augustin is by far the most active participant, especially during the first session, and he is attributed a certain authority by the others perhaps because he is from the prestigious Catholic University. Musimbwa, the other Roman Catholic, is second in terms of the number of contributions. This underlines the impression that the Protestant and Pentecostal academics, mostly from the less well known Université Chrétienne de Kinshasa, are intimidated. This does not contribute to an open debate in the group and the discourse is therefore mostly unilateral, between the facilitator and the person contributing. The model reflects this unease and offers an incredible number of feedback-loops. There is a tendency among these academics to add relations between the variables instead of discussing them. The fact that forty-eight loops pass through the model's central variable, 'love and faith', illustrate this quite dramatically.

In the first session, the sensitivity regarding the use of a European method is a clear indication that 'European' or 'Western' is not a neutral concept for the participants. Here it is also related to power (difference) and the possible or probable abuse of power. However, in the model built by the academics, there is no inclusion of a concept such as 'Western culture'. Augustin argued that concepts such as 'atheism' and 'modernity' are not specifically understood to be Western. Nevertheless, it is interesting to see that the model reflects a negative relationship between science and 'African traditions'. Additionally, the use of a variable such as 'instrumental reason' appears to be due to a desire to speak about the typically Western way of reasoning among the sciences. In contrast, the variable 'encompassing reason' is clearly related to an African way of understanding which is connected to faith. Thus, the use of 'African' and 'Western' do play a role in the understanding of science and faith, but in a rather secret or hidden way.

\footnotetext{
$67 \quad \mathrm{P}_{4}, 90-100,181$.

68 See figure $\mathrm{KA} 2$.

$69 \quad \mathrm{P}_{4}, 122$ : 'Dans les milieux dans les universités on trouve aussi des athées et des fois qu'il a été, il y a (xxx) Messie Metogo qui a mené des études là-dessus, qui a publié un livre « Dieu peut-il mourir en Afrique » et voilà il montre clairement que bel et bien Dieu peut mourir en Afrique ou dans l'Afrique traditionnelle. Il y a toute une tradition à partir des proverbes, à partir des mythes, une tradition de l'incroyance ».
} 
In the second and last session, the cultural difference between 'African' and 'Western' is discussed more openly. In general, science and faith are understood to be compatible. When the case of the doctor is discussed, Espoir, a professor of mechanical construction who identifies himself as a Pentecostal, argues that the doctor limits modernity when she prays with the patient. ${ }^{70} \mathrm{Au}-$ gustin says that this method is typically African, because the human being is not only perceived as a biological being but also as a spiritual one. ${ }^{71}$ This perspective is confirmed by Espoir. ${ }^{72}$ This understanding of the human being thus functions as a paradigmatic example of the African approach to science and faith in that the two belong together as body and soul or spirit. Indirectly, the group indicates that separating the two ('separation' is one of the concepts from their model) is typically European or Western.

However, when they discuss the understanding of science in churches, the perspective becomes more complicated. As we will show in the next chapter, the separation, or even opposition, of faith and science appears to take place in their own contexts as well. Most participants argue that in the churches this understanding of a separation between faith and science has great influence. It is clear that although they think that science and faith belong together, it is particularly difficult for the Protestant-evangelical and Pentecostal participants to completely free themselves from the antagonistic perspective of the churches. As a Roman Catholic, Augustin is not part of these dynamics and argues that there is no sense in demonizing modernity. Nonetheless, his Protestant and Pentecostal partners continue their discourse on the harmful effects of dance, publicity, media, etc.; although they also recognize the positive effects of modernity such as technology. ${ }^{73}$ When the academics discuss the way science is perceived by the representatives of African traditions, Espoir

\footnotetext{
$70 \quad \mathrm{P}_{12}, 67$.

71 P12, 69.

72 P12, 73 : 'Alors, nous acceptons et l'homme se compose, la matière physique ici de l'âme et de l'esprit, l'âme siège des émotions que les psychologues peuvent pénétrer et vous aider à guérir. Les psychologues ne pénètrent pas le spirituel, les psychologues ne pénètrent pas l'esprit, ils pénètrent je veux dire l'âme c'est-à- dire les émotions, l'intelligence et tout ce qui est lié au fait entre, parce que l'âme en fait n'est pas matérielle, ça c'est vrai mais il sert quelque peu de jonction entre le corps physique et l'esprit. Le psychologue peut aller jusqu'à cette jointure, mais c'est les pasteurs, les prêtres qui vont jusqu'au niveau de l'esprit. En Afrique, ce sont les guérisseurs, les différentes sortes de ganga qui allaient jusqu'au niveau spirituel. En comparant cette pratique de ce médecin qui va jusqu'au niveau spirituel et au Ganga c'est-à-dire au guérisseur tout ça, qui allait aussi au niveau spirituel guérir les problèmes physiques, nous pouvons redire l'exemple devant nous de ce docteur je ne sais pas'.

P12, 128 : “[...] à ne pas diaboliser aussi la modernité." P12, 134-137.
} 
argues that the popular belief is that African culture is opposed to modern science. He therefore perceives African scientists, including himself, as "hybrids" because they are "initiated" into the sciences. ${ }^{74}$

\section{$1.3 \cdot 3$}

Continuity between the Discourses of the Two Groups from Kinshasa

Although the discourses of the groups are quite distinct, it seems that the idea of what is called "hybridity" is characteristic of the discourses from Kinshasa. Although some participants, such as the student Congo, claim that there is a move towards the West, that does not mean that the participants fail to identify with what is termed African culture. However, in these discourses there appeared to be a substantially larger distance between the participants and what participants from Yaoundé and Abidjan called 'the village' or the traditional culture of a specific ethnicity. This does not prevent science and faith from being understood through the intercultural dynamics between 'African' and 'Western', as it is in the discourses from Yaoundé and Abidjan. There is an idea about an African approach to science, which is expressed in the words of Gloire about the patient at the hospital and in Augustin's remarks on the holistic or inclusive perspective regarding human beings. However, at the same time, both groups from Kinshasa display an awareness that African cultures or African traditions are more related to faith than to science. When faith and science are contrasted, as was especially the case in the academic groups (elaborated on in the next chapter), African and Western are also opposed to each other.

Part 2: Conceptions of Culture and the Context

In the description and analysis of the discourses of the groups above we have already made some allusions to the correlation between the way culture is

$74 \quad$ P12, 141 : "La tendance générale est de vouloir opposer les traditions africaines à la science que beaucoup appelle la magie des blancs, c'est comme ça que l'opinion publique a tendance à voir dans la science la tradition blanche, la magie c'est-à-dire que c'est eux qui font tout, que lorsque vous suivez, vous apprenez (xxx) à l'université, nous, nous sommes considérés comme étape des noirs initiés à la magie blanche parce que nous avons suivi les sciences appliquées, tel est notre cas que nous avons suivi à l'université, d'autres sont initiés à des sciences (xxx). Donc ils sont perçus par les autres sont nos frères qui n'ont pas eu cette possibilité d'aller suivre les études à l'université donc on est comme des hybrides." 
understood and participants' social and political contexts. Thus, we focus on that correlation before comparing the different discourses of the six groups.

In most groups, especially those from Yaoundé and Abidjan, 'culture' is generally understood in relation to a clan or an ethnic group, and can be characterized as what Robert Schreiter calls an integrated concept of culture (Schreiter 1997, 47-53). ${ }^{75}$ Even when it is used in a more general sense, such as in the student group from Abidjan ("Culture must not dominate faith [...] Africans have more faith in their culture than in Christian faith"), the conception of culture is still related to an integrated understanding of culture - in this case of all Africans. Although there are many Christians among Africans, the Christian faith does not appear to be included in African culture here. Indeed, the debate in the student group from Yaoundé was mainly focussed on the question of whether African cultures could relate positively to Christian faith. It appears that 'African culture' and even more strongly 'African traditions' are related to a fixed perception of these cultures. Thus, in the groups the understanding of 'culture' is often very static (cf. Schreiter 1997, 51). Additionally, 'culture' is often used in combination with 'African' in a negative sense. In the third research session with the students from Yaoundé, Enow's words, “... not only African cultures, but the Bible attacks frontally the cultures of all peoples, ... of the Jews and the Europeans ..." ${ }^{76}$ were received as a new perspective. Therefore, culture seems to have been understood as being related to a specific African 'defect'. This is underlined by the fact that qualifying science as 'Western' or 'European' took some time in this group. ${ }^{77}$ Furthermore, this perspective is not limited to the student group. Félix excused himself when he used the expression "Western science" in the academic group in Yaoundé, and this is of course most telling. These expressions indicate a tendency in the discourses to view 'culture' as an African affair. However, the discourses also reflect positive perceptions of this integrated understanding of culture, as is reflected in contributions by students such as Brice and Patrick, and academics such as Ayuk. This positive perspective is also found in the Abidjan groups (Stephane, for example) and especially in the Kinshasa groups (Gloire and Augustin, for example).

75 More on this definition can be found in Chapters 2 and 6, especially when the definition of Tylor and the perspectives of Tanner, Kim and Robbins are discussed.

$7^{6}$ See footnote 15 .

77 This is an interesting example of an issue we mention in Chapter 2: even without intervention in the debate, challenging a group to express their position will motivate them to make certain attitudes that are latent explicit, and it will therefore influence or even change their views. 
The cultural context of the discourses significantly impacts the way culture and the distinction between 'African' and 'Western' is addressed and evaluated. In the groups from Yaoundé, we saw that ethnic ties played a substantial role in the discussion. Those with a Bamileke background appeared to be particularly critical about the compatibility of their cultural background and the Bible. ${ }^{78}$ Janvier explains that because they are from such a remote region, the Bamileke initially avoided contact with Europeans and rejected their science and education. However, this has since changed, and now they are known as a group that highly appreciates education. ${ }^{79}$ The health sciences student Asta, another Bamileke, adds that nowadays the Bamileke in the Western Highlands even spend a lot of their money on the education of their children. ${ }^{80}$ Martha from the academic group is a good example of how the Bamileke embraced science. Her strategy in the first research session was to exclude the cultural factor from the model, which seems an intelligent way forward for those wanting to assimilate. However, the understanding that their own cultures and traditions are opposed to Christian faith made them a highly visible group during the research sessions. The strategy of those from the north (another remote and discriminated region) such as Junior and Brice is quite different. They are very proud of their cultures and strongly believe in its capacities. Instead of opting for assimilation they struggle for cultural recognition. Another possible influence to highlight here is that of different generations. Ayuk, who disturbed the unity among the academics of the first session, is a young professional and is much closer in age to the students. It seems that emphasising the importance of the proper African character is more common among younger people, who may be under the influence of the Pan- Africanists to whom Patrick referred. Additionally, it is likely that the difference between participants from different ethnic backgrounds is related to the theological differences between the Protestant and Pentecostal churches that dominate differing geographical regions of Cameroon. Varying theological stances concerning the appreciation of traditional cultures could have affected the participants' perspectives. According to Messina and Van Slageren $(2005,28)$, Baptist churches are traditionally strongly represented in the Bamileke region, while in the northern regions the

\footnotetext{
78 See Chapter 3 for information about the Bamileke.

79 P16, 042 :'(...) Dans ma tradition également, on promeut même l'éducation, mais ça je vais un peu, je vais un peu euh nuancer. L'éducation au départ dans ma tradition était une chose dont il fallait se méfier. See also foot note 21'.

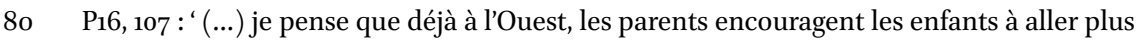
loin dans les études, même s'ils sont pauvres, ils préfèrent même prêter l'argent, prêter les champs'.
} 
Lutherans are dominant. ${ }^{81}$ However, we have insufficient information regarding the participants' ecclesial biographies to relate the within- group differences to any theological differences between the classical Protestant denominations. Additionally, the rapid spread of Pentecostal churches, and the widespread availability of Christian radio and tv stations, must have weakened the traditional ties between regions and the theological domination of denominations. Lamentably, we could not find reliable data regarding the impact of these phenomena.

It is logical that in a context dominated by cultural politics strategies that aim to aid the survival of a people group, such as assimilation, are common ground. However, although these strategies were very obvious in the discourses from Yaoundé, they did not dominate the discourses in either Abidjan or Kinshasa. This was not because cultural politics is not an issue in these contexts, but because another aspect of what is understood as culture appears to be more urgent. The groups from both cities, and especially the students from Abidjan, do sometimes use a similar (integrated) concept of culture as in Yaoundé. However, the term 'culture' is not used in the same ethnic and strategic way as it is in the student group from Yaoundé. In the groups from Abidjan and Kinshasa culture is used in a more flexible way, and in three of the four groups hybridity was used to self-describe the participants' cultural positions. The different use of culture is of course related to the development of the discourse, which was different in every group.

The description of Ivory Coast in Chapter 3 makes it clear why violence and the abuse of power (characteristics of the country's recent history) have made the Ivorians very sensitive to these issues. A certain fear of conflicts was especially noticeable among the academic group (they even included 'conflict' in their model). That Stephane, who as a linguist expressed his love for the diversity of cultures and languages in his country, felt forced to abandon the defence of these languages, illustrates the weight of the fear of violence among the group. French is an important instrument of national unity and communication and is used for scientific research at the university. Stephane was well aware that it would take many decades to achieve the same level of scientific research and teaching in the many native languages of Ivory Coast. This fear of violence affects the use of the terms 'African' and 'Western' in the debates. Although the students from Abidjan expressed a certain pride in their cultures,

81 However, this results in a very general overview. Only the theological difference between the ecumenical traditional Lutherans, and the evangelical Luthériens fraternelles (both influential in the northern part of the country) is truly considerable. 
they did not speak about their specific qualities, as some of the students from Yaoundé did. These traditional cultures were mainly considered to be part of their roots and their pasts. Thus, cultural diversity kept a low profile in their discourses.

Although the recent history of violence appears to be an important factor in this restraint, the low profile of cultural diversity in Abidjan also has other causes. Stephane and other academics pointed to a higher level of assimilation of French culture and language in the Ivory Coast compared to other countries in the region mainly because of Houphouët's administration (see Chapter 3$)^{8}{ }^{82}$ Above we argued that the academics themselves are highly assimilated and thus understand themselves as 'hybrid', which makes them vulnerable in a context that values the importance of ethnic background and pan-Africanism. The last session with the academic group revealed that they perceive Christians to be less bound to African cultures, especially when it comes to faith in magic. This could also be understood as a weakening of their African identity. Together, the fear of conflicts and abuse of power, the years of assimilation, and the understanding of Christians as only partly identifying themselves with traditional culture, create a complex understanding and appreciation of 'African (traditional) cultures' and 'Western culture'.

Finally, we turn to Kinshasa. In contrast to the discourses from Abidjan, violence and war are completely absent from the discourses in Kinshasa. Although Abidjan has had several violent political crises in the last two decades, Kinshasa's political, social, and economic situations are even worse. However, no explicit reference was made to the country's chaotic situation or the frequent use of violence. In the discourses, the rest of the country received little attention. Indeed, the participants seem to perceive Kinshasa as a world of its own. In Chapter 3 we quoted Katrien Pype's remark about "the homogenizing work about ethnicity that is currently going on in Kinshasa" (Pype 2012, 237) which is exactly the cultural ambience that is reflected in the discourses from

$82 \quad$ P9, 142-143: 'Il est vrai que c'est une variété du français euh que ne que ne comprennent pas forcement les français de l'hexagone ... (rires et murmures) mais c'est quand même du français. Mais dans les autres pays d'Afrique occidentale, c'est leurs langues maternelles. Quand vous arrivez au Sénégal, au Burkina-Faso, au Mali, au Benin, au Togo, vous n’allez pas entendre le français en famille. Quand vous attendez français dans la famille, ce qu'il y a un étranger francophone qui est arrivé. ... Mais justement parce que la Côte d'Ivoire est une est une est une nation qui a été beaucoup plus assimilée que les autres. La politique d'assimilation de la France a été plus pratiquée en Côte d'Ivoire parce que le premier président était favorable aux français. (xxx) Il voulait même faire de la Côte d'Ivoire un département d'outre-mer ; c'est parce que les Ivoiriens à l'époque refusaient. [...]'. See Chapter 3 for more on Houphouët. 
Kinshasa. Here culture is not primarily related to what could be called a welldefined tradition that originates in a specific context. In a way the discourses from Kinshasa also use an integrated concept of culture (that is the culture of Kinshasa, La Kinoiserie), but there is also a strong awareness of the hybridity of this cultural situation which makes this conception of culture more flexible. The Kinoiserie reflects what student Congo called "the move to the West." This makes the term 'African' and, in a sense also 'Western', less defined qualifications. The resistance towards the research method made it clear that for the academic group 'Western' still has an imperialistic connotation. Among both the students and the academics in Kinshasa the qualities of a typical 'African' approach to science can be distinguished. Nevertheless, 'Western' can no longer be defined as being completely different because it also refers to some aspects of themselves. Additionally, Pype mentions specific features of the Pentecostal outlook that are intertwined within this culturally hybrid situation. We came across the dualistic outlook of this understanding when the participants divided the world into the realm of God and the realm of the devil (Pype 2012,40 ) in the discourses of both groups (see Chapter 5). In this framework, 'culture' is related to the ambience in the city and the Kinoiserie and is therefore perceived as belonging to the realm of the devil. Culture is therefore heavily criticized by a substantial number of the participants. Both the academics' and the students' discourses bear elements of this dualistic understanding that sometimes surpass the distinction between 'African' and 'Western'.

Part 3: Comparing the Discourses of the Six Groups on 'African' and 'Western'

This chapter aims to show that despite the many differences between the discourses, all the groups understand the discussion about science and faith within a wider framework in which the difference between 'African cultures' (and/ or traditions) and 'Western (or European/ French) culture' plays an important role. The two sections above offer important clues to understanding how every group made sense of this cultural setting of science and faith. In this final section we will clarify the use of the cultural difference between 'African' and 'Western' as used by the six groups. This will mainly be done by addressing the convergences and divergences on this point. We ask ourselves if intercultural framing is an adequate concept to describe what is going on in these groups especially those from Abidjan and Kinshasa. Above we defined this concept as follows: intercultural framing is a dynamic and intentional way of making sense of a subject or theme (in this case science and faith) by relating it to 
different cultural conceptions of this subject or theme. This 'sense making' can be based on certain suppositions, or even a more elaborated theoretical framework, in which different cultural influences are recognized and appreciated. However, interculturally framed or not, we at least need clarity regarding the roles of 'African' and 'Western' in the discourses. This will allow us to have an adequate understanding of the ideas about science and faith expressed in these groups, which will be studied in the next chapter.

If we compare the different group discourses in their social and political contexts, we see a confluence of factors which contribute to the 'intercultural framing. Firstly, there is the history of colonialization which established certain patterns between the culture(s) of the colonizers and the local cultures. In the post-colonial period, the inequality between the two parties that sustained these patterns have not really, or at least not completely, changed. This implies that ambivalent and defensive attitudes towards the ex-colonizers' culture(s) and the proper (traditional) cultures are still in place, and in fact this ambivalence is expressed in every group. ${ }^{83}$

The (majority of the) churches represented by the participants made their contributions to this ambivalence by means of their severe criticism of traditional African cultures (although alternative theological judgements surfaced as well). This is testified to very clearly in the student discourses from all three cities and is confirmed by the academics from Yaoundé and Kinshasa. None of the participants mentioned a similar critical attitude on the part of the churches towards Western culture, although the students from Abidjan mentioned the critical attitude of the churches towards certain academic disciplines. The opposition between church and world (which sometimes evolves into the opposition between God and devil) easily adds to this ambivalent appreciation of what is called African culture as it downgrades trust in society and cultural dynamics. This is particularly clear in the discourses from Kinshasa.

The awareness of hybridity is closely related to the ambivalence concerning African cultures and traditions. This awareness was explicitly worded in both groups from Kinshasa and in the academic group from Abidjan. Hybridity was particularly related to the academic group from Abidjan because of their involvement in 'Western' science.

83 Most explicitly by Ayuk in the second research session with the academics from Yaoundé, but also by Stephane and others in the academic group from Abidjan, and Augustin in the academic group from Kinshasa. Among the students, the two tendencies in the student group from Yaoundé embody this ambivalence. It can also be found in Congo's contribution to the students' discourse in Kinshasa. Finally, the interpretation of science as 'something of the white men' and secret knowledge as 'something typically African' during the second session shows the ambivalence towards both sides. 
Despite these major shared elements, the use of 'Western' and 'African' in the groups is different due to their unique situations and compositions. The opposition between the two tendencies in the student group from Yaoundé (as analysed above) dominates their discourse. Although the majority think that 'African culture' is not compatible with the liberating message of the Bible, the opposite position is also keenly defended by a substantial sub-group. The group is more united when it comes to denouncing the limited, Western perspective of science. In this dynamic, the Bible becomes the judge of all cultures. Although this helps to counterbalance the normality of the Western academy (including Western theology) and underlines a certain 'impartiality' of the Bible, it easily leads to an understanding of the Bible's message being culturally neutral. Such a view reinforces the criticism of African culture and obstructs the development of contextual theologies.

In the first session with the Yaoundé academics, the cultural difference between 'Western' and 'African' did not play a substantial role. It was only during the second research session, when Ayuk attacked science as a colonial affair that confused the people etc., that the intercultural framing of the debate on science and faith began, and a similar field of two tendencies (as was the case in the students group) was made visible. However, Ayuk's affirmative position towards African culture was not really supported by other members of the group. Nevertheless, it helped to discover how the very positive perception of science expressed in the first session was related to a critical understanding of African cultures. Martha even used a dualistic lens to distinguish between scientific knowledge and traditional African knowledge. The two tendencies in the academic group are even more opposed because they do not share the criticism of the Western character of science at university, as is the case in the student group. The opinions in this group were more outspoken and they did not give the Bible the role it received in the student group. Nevertheless, what we call the 'intercultural framing' took place in a similar vein. We conclude that the dynamics in which science and faith are discussed in the two groups from Yaoundé consists of a mix of different, explicitly Christian, appreciations and criticisms of 'Western' and 'African' culture. As we already noted above, both discourses from Yaoundé reflect intercultural framing.

The decision to use the concept 'intercultural framing' was based on the analysis of the discourses from Yaoundé. Although we alleged above that the ambivalence towards 'Western' and 'African' cultures is present in all the discourses, the question is whether intercultural framing is also an adequate and helpful qualification for what is happening in the other groups. When we turn to the two groups from Abidjan, we establish that despite sharing characteristics common in all the discourses, the dynamics here are not the same as those 
in Yaoundé. The use of violence in the past under colonial rule, and especially the recent history of violence by political and ethnic groups, made the participants very sensitive to conflicts. Particularly in the academic group there was a certain fear regarding speaking about 'African cultures' because of its violent potential. Together, the effect of assimilation through science, and the argument that Christians would not share most of the magical part of traditional worldviews and therefore should be more open to scientific investigation, limits the importance of 'African cultures' in their discourse on science and faith. In their focus on epistemology and truth, both Abidjan groups seem to break away from the cultural questions that include the possibility (or probability) of conflict, violence, and regret about (a history of) assimilation. This strategy follows the same pattern as the first session of the academics from Yaoundé and appears to be a specific continuation of the assimilation. This recognition makes it easier to understand why neither the student group nor the academic group successfully included 'culture' during the final research sessions despite the participants indicating they would do so. However, downplaying 'African culture' as a theme in the discourse is not the same as blocking typical structures or logic that could be related to 'African cultures' (which we will argue in the next chapter). Nevertheless, framing the debate on science and faith interculturally does not seem to be the right term to describe the dynamics of the group discourses from Abidjan. Although there is a deep awareness of the intercultural space in which these two themes have been developed, the major strategy shared by participants in both groups is orientated towards the avoidance of an intercultural approach that would openly discuss (the differences between) African and Western culture(s).

Finally, we turn to the groups from Kinshasa. We start with the academics' discourse because of the striking similarities between the model of the students in Yaoundé and that of the academics from Kinshasa. ${ }^{84}$ Despite the apparent similarity between the models there is in fact an interesting difference between the two. In terms of the debate on science and faith, for the academics from Kinshasa there is a direct relation between the cultural differences

84 See models YS2 and KA2 in the Annexes. The model of the students from Yaoundé, YS2, has a similar structure with a variable 'African culture' on the right-hand side and epistemological variables on the left-hand side of the model. At first sight this also seems to be the case in the model built by the academics from Kinshasa: KA2. The relation between the left- and right-hand sides of the model from Kinshasa can be qualified as 'epistemological' and 'cultural' respectively, where both sides have a typically 'Western' and a typically 'African' variable. However, the model from Yaoundé is more complex. Here the difference between Western and African can be recognized in a crucial variable on the left- ('common use of science') and the right-hand sides ('African culture') of the model respectively. 
regarding (Western) 'modernity' and 'African tradition' and the epistemological distinction concerning instrumental and encompassing reason. However, the discourse of the students from Yaoundé underlines the perspective that 'African culture' should be evaluated from a Biblical understanding. This far more critical approach to African culture underlines the proper, independent position of Christian faith in its relation to culture, as understood by Enow. However, in the discourse of the academics from Kinshasa, this critical factor is not really articulated, and as a result the cultural difference between 'African' and 'Western' becomes dominant. The model built by the academics from Kinshasa reflects just a part of their discourse. Notwithstanding the more active participation of the Protestant and Pentecostal academics during the second session, they do not come up with a critical approach to traditional African cultures, as was the case in both groups from Yaoundé. The academics from Kinshasa are mainly critical about what they see as the burdens of modern (city) life. It makes sense that in a context in which people call themselves 'hybrid', the traditional cultures are less criticized. Especially during the model building session, the academics framed the debate on science and faith in a strongly intercultural fashion, which fits their hybrid self-understanding. The discourse in the student group reflected this focus on hybridity even more. Here there was no substantial critical assessment of 'African cultures', but rather an interest in how both African (in a more general sense) and Western culture(s) has shaped them 'inside' (as Congo puts it). The intercultural framing here is quite distinct from what happened in the groups from Yaoundé, where the framing was a result of the two tendencies that interacted and diverged regarding the appreciation of 'African culture'. In the discourses from Kinshasa, it is a widely shared understanding of hybridity that makes an intercultural perspective necessary.

We conclude that intercultural framing is not an adequate term to qualify the processes that took place in all the six discourses on science and faith. The strategy of the groups from Abidjan did not lead to openly discussing the cultural differences and influences, but rather to concealing these. Nevertheless, the importance of cultural differences was recognized in all the groups and are therefore important to the content of all the discourses. Although the discourses from Yaoundé and Kinshasa are (intentionally) interculturally framed, there is an interesting difference between these framings (as just explained). In the next chapter we will depart from the various strategies and framings concerning culture that we have discovered so far and will address the understandings of science and faith in the six groups.

Finally, we present a table of comparison which may help to provide an overview of the six groups: 


\section{Group Group characteristics Handling Cultural difference (model built)}

\begin{tabular}{|c|c|c|}
\hline $\begin{array}{l}\text { Yaoundé } \\
\text { Students } \\
(\text { model YS2) }\end{array}$ & $\begin{array}{l}\text { Less women; constant } \\
\text { participation; varied } \\
\text { disciplinary } \\
\text { backgrounds; high } \\
\text { ethnic awareness. }\end{array}$ & $\begin{array}{l}\text { Two tendencies: one more critical } \\
\text { towards traditional culture, other } \\
\text { more positive; shared criticism of } \\
\text { Western science; intercultural } \\
\text { framing from the start. }\end{array}$ \\
\hline $\begin{array}{l}\text { Yaoundé } \\
\text { Academics } \\
(\text { model YA2 })\end{array}$ & $\begin{array}{l}\text { Only last session better } \\
\text { gender balance; strong } \\
\text { presence natural } \\
\text { sciences; inconstant } \\
\text { participation; ethnic } \\
\text { awareness. }\end{array}$ & $\begin{array}{l}\text { Two tendencies: one (dominant) } \\
\text { critical, other affirmative towards } \\
\text { traditional culture; intercultural } \\
\text { framing from } 2 \text { nd session. }\end{array}$ \\
\hline
\end{tabular}

Abidjan

Students

(model AS2)

Abidjan

Academics

(model AA2)

Kinshasa

Students

(models KS2 and $\left.\mathrm{KS}_{3}\right)$

Kinshasa

Academics (models KA2)
First session nice gender bias and lively debate; strong presencence humanities, less natural sciences; small group with constant participation; ethnic awareness but not a major theme. Male dominated; varied disciplinary backgrounds; ethnicity was a minor theme.

Fewer women; strong presence of technical and applied sciences; Pentecostal majority; weak ethnic awareness.

No women; strong presence of theologians and philosophers; denominationally diverse; ethnicity was not an issue.
Strong cultural awareness; focus on power and suppression; avoiding intercultural framing.

Strong cultural awareness, hybrid self-definition; fear of conflicts; downplaying cultural differences as assimilation strategy; power and suppression dominate the discourse; no intercultural framing. World - church divide is more important than the cultural divide; African - Western divide is discussed in relation to hybrid self-understanding and related to a certain form of intercultural framing. Part of the group underlines the opposition of world and church; African - Western divide leads to a proper form of intercultural framing which is related to hybrid self-understanding. 